\title{
DEMONETIZATION AND IMPROVISATION OF VALUE CHAIN DYNAMIC IN AFGHANISTAN: AN EXPLORATORY STUDY
}

\author{
Abdul Masood Panah \\ PhD Scholar \\ Department of Commerce \\ Mangalore University, Mangalagangothri \\ Mangalore, Karnataka, India \\ E-mail: mazzpanah@gmail.com \\ Dr. Y. Muniraju \\ Professor \& Dean \\ Department of Commerce \\ Mangalore University, Mangalagangothri \\ Mangalore, Karnataka, India \\ E-mail: drymuniraju97@gmail.com
}

\begin{abstract}
Demonetization is the elimination of the backing of the money granted by law to the notes is, therefore, legal tender. On Wednesday_ September 2002, the new president of the transition government announced from television to the people of Afghanistan that the decision had been reached in response to Afghan and foreign experts. They had advised the new Government to replace the currency and reform Afghanistan's banking system. "This will help in controlling the massive inflation and stabilize the economy. A survey was conducted with a pre-tested questionnaire among the common public in Kabul and Parwan's main two provinces to collect their views on factors associated with demonetization in Afghanistan. PCA (Principal component analysis) technique has been used for factor extraction and dimension reduction using the Varimax orthogonal rotation. The top key factors related to the implementation of demonetization have been identified as socio-economic factors, public hardships, challenges, and implementation challenges. The survey data's descriptive analysis shows that most survey respondents either 'strongly agree' or 'agree' with the 19 measures on perception and opinion of the common man (general public) on demonetization in Afghanistan.
\end{abstract}

Keywords: Factors Influencing Demonetization, Demonetization, Macro-Economic, Monetary System, Paper Currency.

\section{INTRODUCTION}

The monetary system is one of the essential systems in a country. It's a system developed in the governments' macroeconomic structure to facilitate exchange, generate and measure wealth and debt by using the currency. Money is the most extensively used payment instrument for centuries, and today all over the world. Therefore, it will fulfill the needs; will continue to be a globally used payment tool (Knaap, Vries, \& Boesenach, 2018). One of the most critical 
purposes of the financial system is to possess legal sanctions and backed by the law that gives legal tender to the currency. Paper money and coins are the general forms of legal tender in most countries (Knaap et al., 2018). Due to any economic decisions, the Government can decline the individual coins and banknotes' legal tender (Ramchandra Gowda, Aswatha Narayana, Ravi, \& Srinivas, 2014). Demonetization is the process of banning a regular currency circulation in the economy of a country. Therefore, it refers to the process of deciding that individual coins and banknotes can no longer be in use for goods and services. When there is a change of national currency in a country, the current forms of money or types of payments are banned from circulation and retired, often replaced with the new currency (Ghosh, Chandrasekhar, \& Patnaik, 2017).

Due to hyperinflation during the 1990s by 2001 in Afghanistan, the money lost its value. It was almost valueless against foreign currency; there were also multiple types of local currencies in circulation (Ghani \& Lockhart, 2008). In late 2002, the transitional Government demonetized the old money and introduced a single coin for all the countries (DAB, 2006; Bennett, 2003). Therefore, this paper attempts to identify the critical factors associated with the implementation of demonetization in Afghanistan. We also studied the value chain dynamics of demonetization in Afghanistan. It is also an attempt to probe these issues to assess its impact on the common man (general public).The exploratory factor analysis results explored socioeconomic factors, public hardships and challenges, and challenges for implementation, as perceived by the common man (general public) as the highly significant critical factors that affect demonetization of Afghanistan's value chain dynamics. Despite the challenges demonetization as the most successful decision created value chain dynamics to Afghanistan's economy and the general public, the excessive inflation resolved, re-establish Afghani's credibility both locally and globally, the circulation of various regional currencies stopped, better aligning global value chains with Afghanistan's international trade dynamics partners and regional neighbor countries (DAB, 2006). Also, demonetization made the transaction easy for the common man (general public). They do not need to carry huge bundles of money to buy their essential goods and services (Ghani \& Lockhart, 2008). Therefore, the improvisation of the value chain in Afghanistan's economy is due to the most parts' demonetization.

\section{LITERATURE REVIEW}

The Indian economy was severely impacted by demonetization. All the small and medium-size businesses affected, and the common man and poor people suffered immense complicity in adjusting to using digital technology. As the primary purpose of demonetization was to eradicate black money, counterfeit currency, and terrorist funding (Chandrasekhar \& Ghosh, 2018; Chodorow-Reich, Gopinath, Mishra, \& Narayanan, 2020; Kumar, 2017; Mahajan \& Singla, 2017; Mukherjee, 2019; Sivathanu, 2019; Thakur \& Srivastava, 2013), studied the impact of demonetization in the Indian economy. (Ghosh, 2016; Kumar, 2017; Mahajan \& Singla, 2017; Thakur \& Srivastava, 2013), found that the purpose of demonetization is not served as the cashless society was a bit troublesome to the general public. However, (Chodorow-Reich et al., 2020; Mukherjee, 2019) found that demonetization increased India's digital transactions. (Sivathanu, 2019), found that the target of demonetization partially served. The behavioral intention to use innovation resistance affects the use of a cashless payment system. (Swain \& Das, 2018), Found that demonetization had a positive impact on eliminating black money, counterfeit currency, and terrorist funding. On the other hand, (Singh, Sawhney, \& Kahlon, 2018) found that the Indian Government initiated the common man affected by the demonetization policy. However, the studies show out of 29 states that only nine states were 
against the demonetization policy's execution. (Briceno \& de Hurtado, 2019; Dash, 2017; Mukherjee, 2019), found that demonetization had negatively impacted the Indian economy, as the poor people suffered to deal with their daily lives. (Beg \& Joshi, 2017) found that demonetization brought many constrain for the Indian citizens. They faced lots of difficulties and hardships, standing in lines for exchanging their old currencies. (Prasad, 2019)found that demonetization helped real estate business practice on the right track. (Goel, 2018; Sharma, 2019) Seen that demonetization eradicated the stocked and stacked currencies and cleaned the economy's financial system in India. (Sharma, 2019) studied the impact of demonetization on the Indian economy for the period of 1970-2017. The result shows in early 1970, the black money contribution to the Indian GDP was 30\%; however, after several reforms reduced to $15 \%$ of the official GDP, the last estimate in the year 2017 reveals 23849 billion Indian rupees, which was $14 \%$ of the official Indian GDP. (Vij, 2018). The short-term impact of demonetization was quite visible; however, the long-term effect is unknown.

\section{Objectives of the study}

- This paper aims to identify the critical factors associated with the implementation of demonetization in Afghanistan.

- To study the value chain dynamics of demonetization in Afghanistan.

- To identify and analyze the common man's perception and opinion (general public) on Afghanistan's demonetization.

\section{IMPORTANCE OF THE STUDY}

Demonetization has both advantages and disadvantages in Afghanistan. It requires proper planning and implementation. Otherwise, it's more drawbacks to the economy, particularly to the common man (general public). Demonetization can help tackle black money and parallel economy; money received through corruption will become worthless as such a person might not be able to explain the source. Demonetization can provide a fiscal boost for the Government. The central bank might declare dividends to the Government for the currency that does not return into the system. Demonetization can help check counterfeit or fake money in circulation. Fake currency is responsible for terrorism funding, running parallel economy, or shadow economy. It affects banking institutions, share markets, and other vital sectors; to control and avoid this, demonetization is one of the best models to mitigate and control inflation. It also helps to manage the economy, significantly bring essential goods and services at a lower cost to serve the common man (general public).

The research scope in demonetization and improvisation of Afghanistan's value chain dynamic is in the chorus with this momentum. As demonetization acts as a fortune and chaos bringer at the same time, it makes itself very attractive to numerous researchers to find and explore its untapped dimensions. As per the authors' knowledge, this topic is the first attempted to study in Afghanistan. The researcher was going to study in-depth, particularly the demonetization and improvisation of Afghanistan's value chain. Socio-economic inclusion is the improvisation of the terms on which individuals and groups are taking part in a community (Knaap et al., 2018). The demonetization affects the common man (general public) if not properly managed; the central bank and other banks immediately supply sufficient money to the economy. This is a significant problem and difficulties faced by Afghanistan. The objectives of demonetization purpose served in Afghanistan. Under the demonetization, the system requires a good ecosystem, digital infrastructure, and digitalized people. It shows the gap in the study. We are going to have an effort to fill this gap. So the one hand, it could fill the gap by contributing to 
the body of knowledge. On the other hand, it could serve as a reference for policymakers for better implementations. According to (Singh, 2006), the problem's statement attempts to focus on a stated aim, which gives direction to the research process.

\section{Instrument design}

\section{RESEARCH METHODOLOGY}

We obtained the variables measured for this research model from a review of relevant literature. The researchers further carried out open-ended, unstructured interviews with some of the currency reform and Afghanistan experts' executive delegates to identify the reason for this move's initiation. And the challenges faced by them at the time of implementing such a national movement in the country. What challenges are met by the common public in the process of exchanging their old currency? And the best practice management methods for resolving these challenges are interviews done by journalists, magazines, and news that exist through the internet (Focus on Introduction of New Currency, 2002).

\section{Sample Selection, sampling technique \& data collection}

For this study, the respondents are the common Public in Afghanistan. This study source was from different categories: daily wage workers, agriculturalists, small business holders, and people who are part of the unorganized labor class. We used a non-probabilistic convenient sampling technique by surveying 250 respondents in the Kabul and Parwan provinces of Afghanistan. Kabul \& Parwan are the provinces where the country's maximum population is living compared to other regions. The researcher could also have travel facilities to distribute the questionnaire among the public across these provinces' various districts.

Table 1. Demographic profile of the respondents

\begin{tabular}{|c|c|c|c|}
\hline Details & Categories & Frequency & \% of respondents \\
\hline Age & $25-30$ & 109 & 43.6 \\
& $31-35$ & 47 & 18.8 \\
& $36-40$ & 47 & 18.8 \\
& $41-45$ & 18 & 7.2 \\
& $46-50$ & 9 & 3.6 \\
& 51 and Above & 20 & 8.0 \\
& Total & $\mathbf{2 5 0}$ & $\mathbf{1 0 0 . 0}$ \\
\hline \multirow{2}{*}{ Gender } & Male & 204 & 81.6 \\
& Female & 46 & 18.4 \\
& Total & $\mathbf{2 5 0}$ & $\mathbf{1 0 0 . 0}$ \\
\hline Education & Illiterate & 24 & 18.0 \\
& Up to primary school & 14 & 9.6 \\
& Up to $10^{\text {th }}$ standard school & 69 & 5.6 \\
& Up to 12 1 thaditional school & 69 & 27.6 \\
& Undergraduate & 29 & 27.6 \\
& Post-graduate & $\mathbf{2 5 0}$ & 11.6 \\
& Total & 210 & $\mathbf{1 0 0 . 0}$ \\
\hline \multirow{5}{*}{ Family size } & Join family & 40 & 84.0 \\
& Nuclear family & $\mathbf{2 5 0}$ & 16.0 \\
& Total & $\mathbf{1 0 0 . 0}$ \\
\hline
\end{tabular}




\begin{tabular}{|c|c|c|c|}
\hline Occupation & Daily wage earners & 50 & 20.0 \\
& Agriculturalist & 83 & 33.2 \\
& Shopkeeper & 23 & 9.2 \\
& Small business & 25 & 10.0 \\
& Others & 69 & 27.6 \\
& Total & $\mathbf{2 5 0}$ & $\mathbf{1 0 0 . 0}$ \\
\hline
\end{tabular}

Source: Authors' Computation based on the questionnaire

The respondent's demographic profile shows the Age, Gender, Education, Family size, and occupation. 109 respondents, representing 43.6 percent of the total respondents, are 25 to 30 , followed by age group 31 to 35 and 36 to 40 . Each group represents 47 respondents and 18.8 percent of the total respondents. Similarly, 46 to 50 and above 51 represent 3.6 and 8.0 percent of the respondents. Likewise, the gender of the respondents dominated by male and female, 204 respondents, and 81.6 percent are male and 46 respondents and 18.4 percent are female. We have also asked about education, family size, and occupation of the respondents represented in table 1. Under the organized sector, daily wage workers dominate the respondents, followed by agricultural shopkeepers and small business holders. Similarly, under the unorganized labor class, the respondents are housewives (homemakers) and jobless people.

\section{Data Analysis}

\section{Exploratory Factor Analysis}

We used the PCA (Principal component analysis) technique for factor extraction and dimension reduction using the Varimax orthogonal rotation (DeVellis, 2016; Netemeyer, Bearden, \& Sharma, 2003), with Kaiser Normalization. And we tested for validity and reliability to determine the factor analysis strength (Kaiser, 1960). It is done by the KMO and Bartlett's test of sphericity. The significance of the correlation matrix is conducted using Bartlett's test of sphericity. The value of KMO statistics should be greater than 0.5. The KMO statistic compares the observed correlation coefficients' magnitude with the importance of partial correlation coefficients (Chawla \& Sondhi, 2016). Following the factor analysis using the PCA technique for the extraction of factors, we removed items with lower communalities $(<0.5)$ and lower cross-loading $(<0.45)$. Like, banks' quality of service, insufficiency of the window period for the exchange of currency, and public awareness of demonetization ( Hair, Black, Babin, Anderson, \& Tatham, 1998).

\section{Reliability analysis}

To determine the reliability of the factors, we used Cronbach's alpha. A value of 0.60 and higher was sufficient to know whether the items had internal consistency and measure the same element (Nair \& Bhattacharyya, 2019).

\section{RESULTS AND DISCUSSION}

The results of the factors affecting demonetization in Afghanistan has presented in the following sections

Table 2. Number of Items in the Scaled Questionnaire

\begin{tabular}{|l|c|}
\hline \multicolumn{1}{|c|}{ Scaled Question } & No. of Items at the beginning \\
\hline (Demonetization as Economic Decision) & 3 \\
\hline (Public Opinion on Demonetization) & 3 \\
\hline
\end{tabular}




\begin{tabular}{|c|c|}
\hline (Impact of Demonetization on Business) & 3 \\
\hline Total & $\mathbf{9}$ \\
\hline
\end{tabular}

Source: Authors' computation based on the questionnaire

Table 2 shows the number of items measured on the five-point Likert scale for factor analysis. We categorized nine variables under three heads: demonetization as economic decisions, public opinion on demonetization, and impact of demonetization on business.

Table 3. Kaiser-Meyer-Olkin and Bartlett's test for Sampling Adequacy

\begin{tabular}{|l|l|r|}
\hline Kaiser-Meyer-Olkin Measure of Sampling Adequacy. & .723 \\
\hline \multirow{3}{*}{ Bartlett's Test of Sphericity } & Approx. Chi-Square & 555.278 \\
\cline { 2 - 3 } & df & 36 \\
\cline { 2 - 3 } & Sig. & .000 \\
\hline
\end{tabular}

\section{Source: SPSS output}

Table 3 represents the KMO Bartlett test for Sphericity and Sampling adequacy. The $\mathrm{KMO}$ value is $0.723(>0.5)$ indicates that the sample is adequate, and it shows that the factor analysis is ample for the given set of data (Kaiser, 1974). The chi-square value is significant at a $5 \%$ level of significance $(\mathrm{p}<0.05)$, indicating that the factor analysis is appropriate.

Table 4. Communalities for the Items retained in the analysis

\begin{tabular}{|c|c|c|c|}
\hline $\begin{array}{l}\text { Item } \\
\text { No. }\end{array}$ & Communalities & Initial & Extraction \\
\hline & Demonetization as Economic Decision & & \\
\hline 1 & $\begin{array}{l}\text { The decision taken by the Government to demolish old } \\
\text { currency and introduce new money was appropriate } \\
\text { and helped the economic growth. }\end{array}$ & 1 & 0.751 \\
\hline 2 & $\begin{array}{l}\text { Lack of prior preparation for the introduction of a new } \\
\text { currency created hardship for the common man. }\end{array}$ & 1 & 0.704 \\
\hline \multirow[t]{2}{*}{3} & $\begin{array}{l}\text { The timing of the demonetization move was } \\
\text { appropriate. }\end{array}$ & 1 & 0.687 \\
\hline & Public Opinion on Demonetisation & & \\
\hline 4 & $\begin{array}{l}\text { Managing daily household requirement was difficult } \\
\text { during the demonetization. }\end{array}$ & 1 & 0.65 \\
\hline 5 & $\begin{array}{l}\text { You have faced many problems while purchasing } \\
\text { goods and services with old currency. }\end{array}$ & 1 & 0.611 \\
\hline \multirow[t]{2}{*}{6} & Demonetization adversely affected my day to day life. & 1 & 0.578 \\
\hline & Impact of Demonetization on Business & & \\
\hline 7 & Demonetization adversely affected little shops. & 1 & 0.575 \\
\hline 8 & Demonetization adversely affected contract laborers. & 1 & 0.626 \\
\hline 9 & $\begin{array}{l}\text { Demonetizations adversely affect the other aspect of } \\
\text { the informal economy. }\end{array}$ & 1 & 0.521 \\
\hline
\end{tabular}


Communality points out how much of each variable is accounted for by the underlying factors taken together. It measures the proportion of the variable's variation explained by the elements (Chawla \& Sondhi, 2016).A relatively high commonality shows that not much of the variable is left over after whatever the factors represent is taken into consideration. (Chawla \& Sondhi, 2016).Table 4 shows the communalities for the variables. Under demonetization as an economic decision, we found that the first variable's commonalities or variance are 0.751 . Which means the decision was taken by the Government to demolish old currency and introduce new money was appropriate and helped the economic growth, is explained $75.1 \%$ by factors. Similarly, all the nine variables have commonalities of equal or higher than the threshold value of 0.5 , meaning that the variables are internally consistent and reliable.

Table 5. Total Variance Explained

\begin{tabular}{|c|c|c|c|c|c|c|c|c|c|}
\hline $\begin{array}{c}\text { Co } \\
\text { mp } \\
\text { one } \\
\text { nt }\end{array}$ & \multicolumn{3}{|c|}{ Initial Eigen values } & \multicolumn{3}{c|}{$\begin{array}{c}\text { Extraction Sums of Squared } \\
\text { Loadings }\end{array}$} & \multicolumn{3}{c|}{ Rotation Sums of Squared } \\
Loadings
\end{tabular}

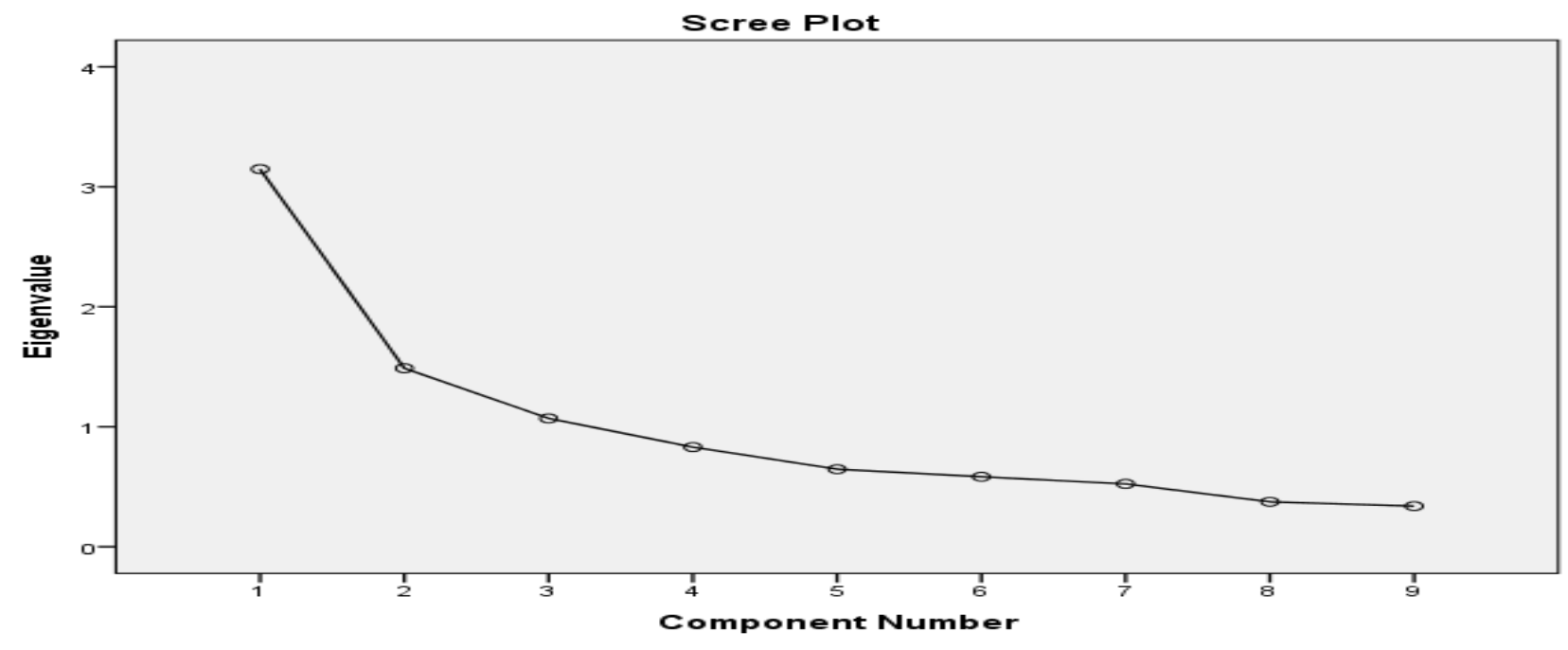

Figure 1. Scree Plot 
The Scree-test showed three factors as optimal against what was suggested by default in SPSS (i.e., Eigen Value > 1) (Cattell, 1966; Kaiser, 1960). Three factors have been extracted, such as Socio-economic factors, public hardships, and challenges, challenges for implementation. The first factor is including of four variables, which show a $34.971 \%$ variance. Factor second is including of three variables, which reveal a $16.530 \%$ variance. Element three includes two variable and $11.882 \%$ of the conflict. The three principal components (factors) included nine items and explained $63.383 \%$ of the total variance (see. Table 5).

Table 6. Factor Loadings of the Rotated Component Matrix

\begin{tabular}{|c|c|c|c|}
\hline \multirow[t]{2}{*}{ Variables } & \multicolumn{3}{|c|}{ Component } \\
\hline & FA1 & FA2 & FA3 \\
\hline Demonetization adversely affected contract laborers. & .769 & & \\
\hline Demonetization adversely affected little shops. & .700 & & \\
\hline $\begin{array}{l}\text { Demonetization adversely affects the other aspect of the informal } \\
\text { economy. }\end{array}$ & .699 & & \\
\hline Demonetization adversely affected my day to day life. & .674 & & \\
\hline $\begin{array}{l}\text { Lack of prior preparation for the introduction of a new currency } \\
\text { created hardship for the common man. }\end{array}$ & & .836 & \\
\hline $\begin{array}{l}\text { You have faced many problems while purchasing goods and } \\
\text { services with old currency. }\end{array}$ & & .754 & \\
\hline $\begin{array}{l}\text { Managing daily household requirement was difficult during the } \\
\text { demonetization. }\end{array}$ & & .681 & \\
\hline $\begin{array}{l}\text { The decision taken by the Government to demolish old currency } \\
\text { and introduce new money was appropriate and helped the } \\
\text { economic growth. }\end{array}$ & & & .859 \\
\hline The timing of the demonetization move was appropriate. & & & .821 \\
\hline \multicolumn{4}{|c|}{$\begin{array}{l}\text { Extraction Method: Principal Component Analysis. } \\
\text { Rotation Method:Varimax with Kaiser Normalization. }\end{array}$} \\
\hline \multicolumn{4}{|l|}{ a. Rotation converged in 5 iterations. } \\
\hline
\end{tabular}

Table 06 shows the component matrix. The rotation's purpose is to have the factor loading to either close to zero or -1 or +1 . It means that the factor loading is high on some variablesand low on some other variables (Chawla \& Sondhi, 2016). In the present study, the results obtained after Varimax rotations are represented in table 6.

Table 7. Reliability Analysis for All Factors

\begin{tabular}{|l|c|}
\hline \multicolumn{1}{|c|}{ Factors } & Cronbach Alpha \\
\hline FA1 (Socio-economic factors) & 0.725 \\
\hline FA2 (Public Hardship \& Challenges) & 0.724 \\
\hline FA3 (Challenges for Implementation) & 0.619 \\
\hline
\end{tabular}

Source: Authors' computation

Reliability analysis for all factors has been checked by calculating Cronbach's alpha for the Likert-scale scale variables in each of the elements that are > 0.06 (Nair \& Bhattacharyya, 
2019). Cronbach's alpha is as follows, for the FA1 (Socio-economic impact factors) is 0.725 , Cronbach's $\alpha$ for FA2 (Public Hardship \& Challenges) is 0.724, Cronbach's $\alpha$ for FA3 (Challenges for Implementation) are 0.619, respectively. (See table 7).

\begin{tabular}{|l|l|l|l|l|l|l|}
\hline \multicolumn{7}{|c|}{ FA1 Socio-economic factor } \\
\hline
\end{tabular}

Figure 2. Percentage of Response on Socio-Economic Factor Source: Authors' Computation based on the factor.

\begin{tabular}{|l|l|l|l|l|l|l|l|}
\hline \multicolumn{7}{|l|}{ FA2 Public Hardship \& Challenges } \\
\hline
\end{tabular}

Figure 3. Percentage of Response on Public Hardship \& Challenges Factor Source: Authors' Computation based on the factor. 


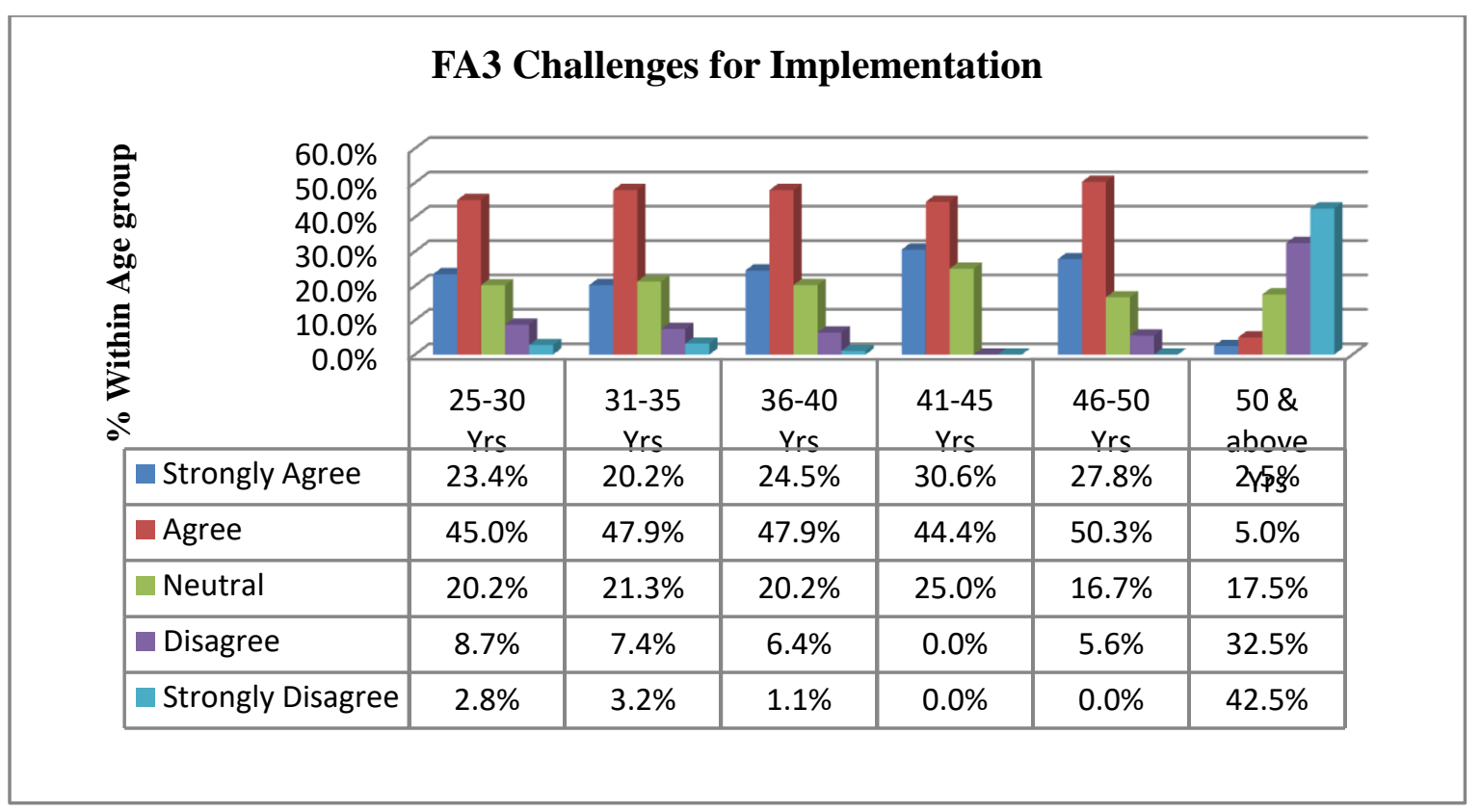

Figure 4. Percentage of Response on Challenges for Implementation Factor Source: Authors' Computation based on the factor.

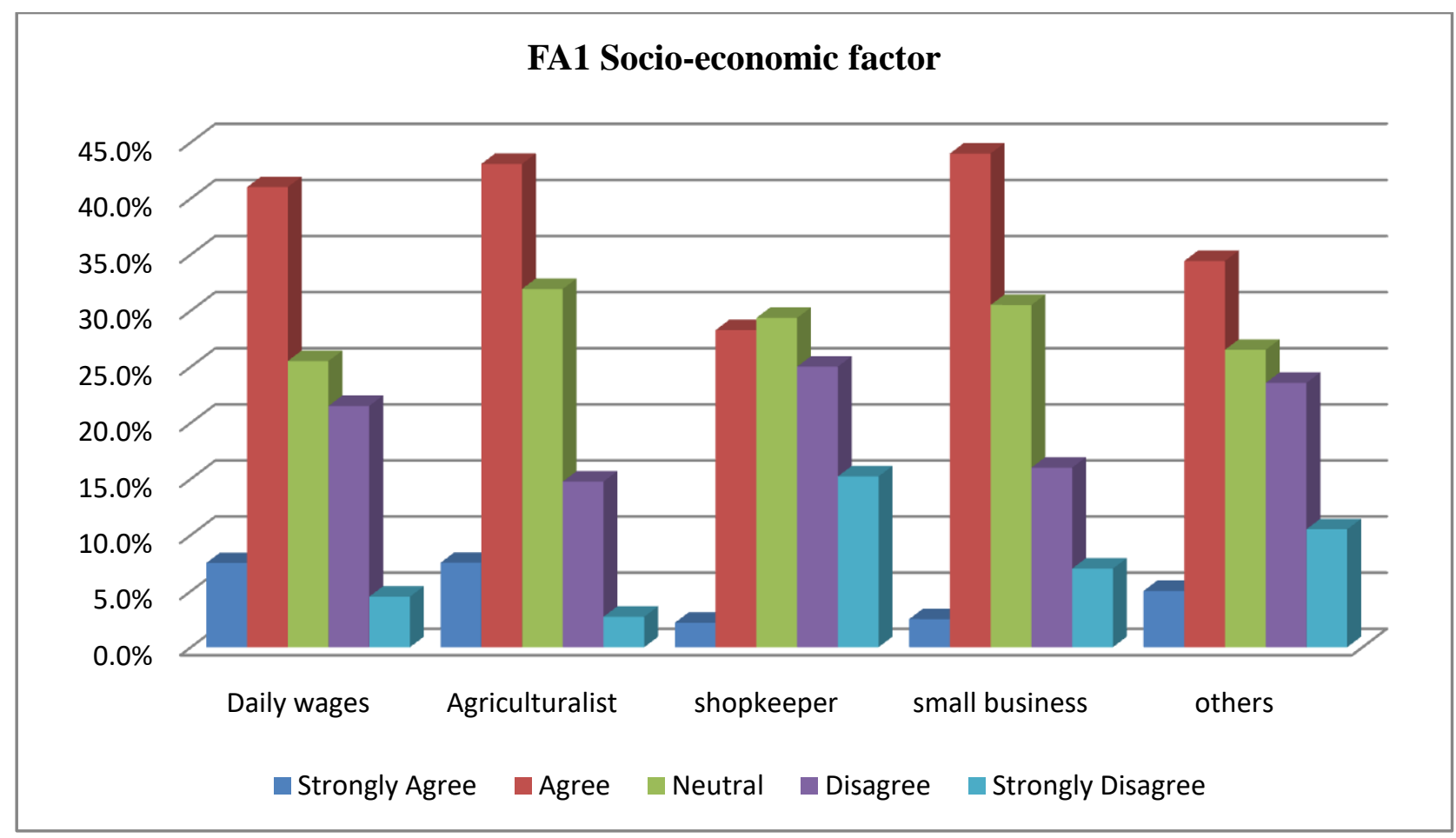

Figure 5. Percentage of Response on Socio-economic Factor

Source: Authors' Computation based on the factor. 


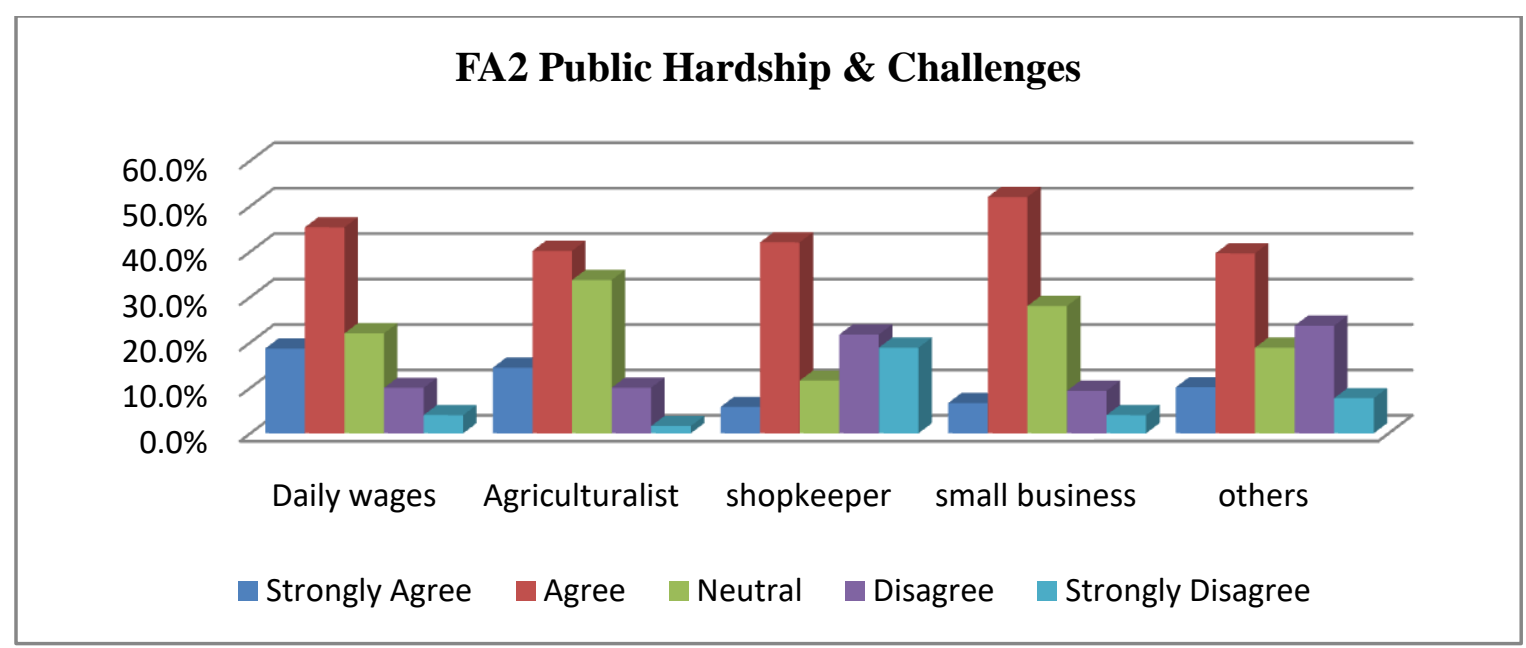

Figure 6. Percentage of Response on Public Hardship \& Challenges factor Source: Authors' Computation based on the factor.

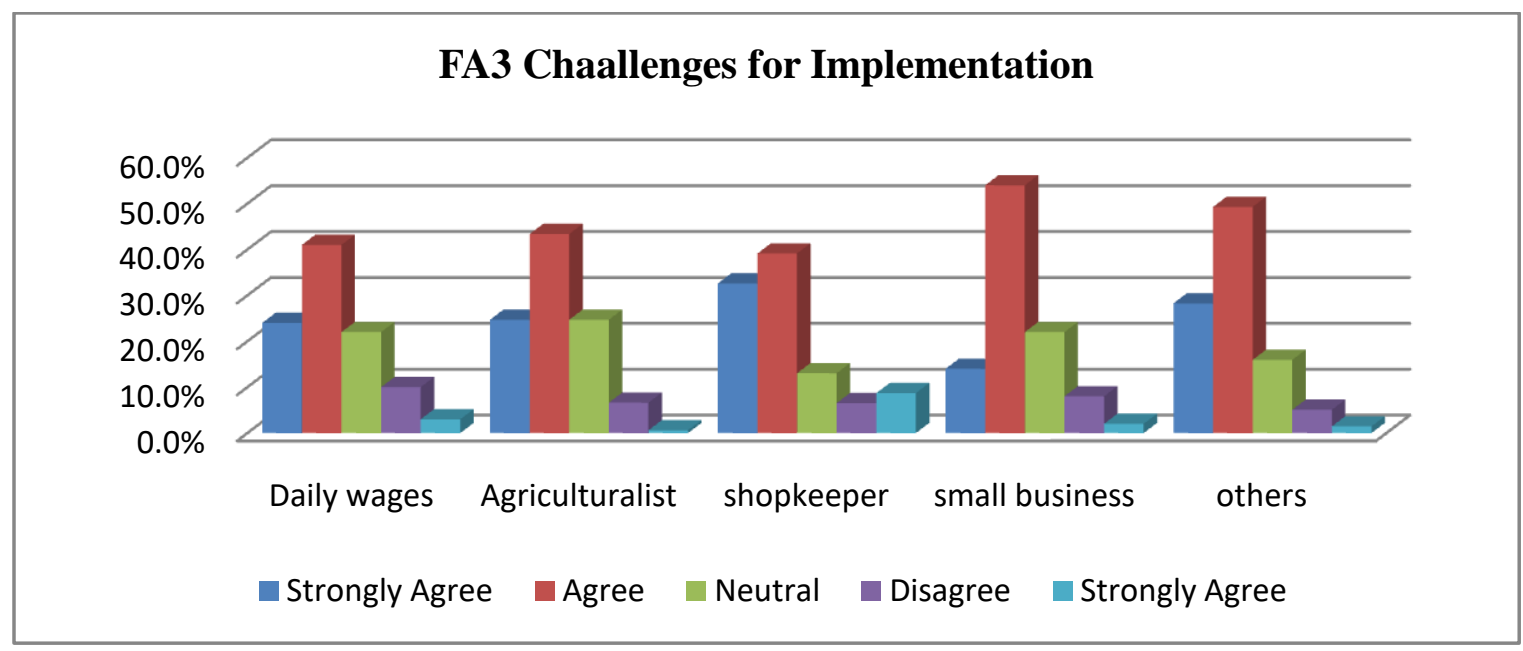

Figure 7. Percentage of Response on Challenges for Implementation factor Source: Authors' Computation based on the factor.

Socio-economic issues, public hardships, and challenges, and challenges for implementation as perceived by different categories of the respondents among the common man (general public) such as daily wage workers, agriculturalists, small business holders, and other groups of people are the top three highly significant factors that affect the demonetization and improvisation of the value chain dynamic in Afghanistan. Apart from the challenges faced by the implementers and the common man, the demonetization's value chain dynamics are considerable. For the first time after decades of war, a single currency was established quickly and gained control over the money's excessive issuance by different individuals (DAB, 2006). Demonetization paved the way to stabilize its value; this recovers the economist's ability to assess the alternatives and stimulate better economic effectiveness and growth. It also better conserves the amount of capital held in monetary form and thus motivates saving (Panah \& Muniraju, 2019). Demonetization made the transaction much simpler the common man (general public) does not need to carry huge bundles of money to buy essential goods and services (Ghani \& Lockhart, 2008). The excessive inflation resolved, the shift to reasonable levels of inflation 
assistances re-establish Afghani's credibility both locally and globally, eliminated the circulation of various regional currencies, better aligning global value chains with Afghanistan's international trade dynamics partners and regional neighbor countries especially, India and Pakistan. Demonetization also brought a value chain in expressing and recording the monetary values, which have been exceedingly useful for practical reasons (DAB, 2006). Remarkable progress has been made in establishing private and Government banks and the country's digitalized banking system in the past few years. Therefore, it reveals the improvisation of the value chain dynamics of demonetization in Afghanistan.

\section{Socio-Economic Issues}

Socio-economic issues are the factor that caused the demonetization. There were multiple types of currency in circulation before demonetization in the country. The common man (general public) had suffered due to demonetization. There has been some misunderstanding about its implications. Some people mistakenly think that dropping three zeros has reduced the value of their claims denominated in Afghani. The New Afghani was demonetized at a ratio of 1 to 1000 of the old Afghani (DAB, 2006). Well, before the three zeros were removed. Some have argued that deposits they made many years ago or contracts they entered into many years ago lost value because of the conversion to the new Afghani. The eliminating of three zeros had created some controversy and in some quarters. Therefore, such socio-economic issues among the common man (general public) are perceived as the most significant factor at demonetization time. However, (DAB, 2006)reveals that the old Afghani in circulation before 2002 had already lost considerable value due to high inflation due to printing too much currency by different private individuals.

\section{Public hardship and challenges}

Public hardship and challenges are the second factors that adversely affect the demonetization. More than 26 million people were given a few months to bring the demonetized notes of their life's savings and exchange it with the new currency, which would be no longer a legal tender. Afghanistan is mountainous terrain and war-stricken country with destroyed infrastructure and eroded social capital institutions, often impossible bandit-ridden countries, where transportation is limited. Many people are illiterate, newspapers and video-media were mostly absent at the time of demonetization. Many people live in villages far from the banks and money exchange dealers and war-shattered infrastructure (Focus on Introduction of New Currency, 2002). Therefore, such challenges are perceived as highly significant factors related to demonetization in Afghanistan.

\section{Challenges for Implementation}

Challenges for implementation are the factor influenced demonetization of Afghanistan. There were substantial logistical, promotional, communication challenges for the performance of demonetization. Despite difficult circumstances, the Government has made commendable efforts to put in place sound economic policies. However, the progress in strengthening macroeconomic management continued to be slow, given the weak starting point and limited administrative capacity, the fragile political situation, and the fact that the Government did not have full control over the many parts of the country. Great preparations and allowances for the currency exchange were needed, such as air-lifting cash by helicopter to remote exchange points and allowing sufficient time for all Afghans to bring in old notes and exchange them for the new 
currency (Bennett, 2003). Therefore confirms that challenges for implementation are another considerable factor causing demonetization in Afghanistan.

\section{FINDINGS AND CONCLUSION}

The qualitative findings from the available literature about demonetization and improvisation of value chain dynamics in Afghanistan: an exploratory study validated by distributing a questionnaire survey. The survey's main objective was to gather the respondents' perceptions and opinions on the 35 measures stated in individual statements written in the questionnaire. The researcher distributed the questionnaire among the common man (general public) in Afghanistan. The study explored the most vital demonetization factors that impacted the common man (general public) perception in Afghanistan. This paper's main objective was to identify the factors associated with implementing demonetization in Afghanistan from the common (general public) viewpoint and review Afghanistan's demonetization's value chain dynamics. It is also an attempt to study these issues to assess its impact on the common man (general public).The demographic characteristics of the respondents are represented (see Table 1).The result of the exploratory factor analysis, the principal component analysis, reveals that the most critical factors associated with the implementation of demonetization that affect the improvisation of value chain dynamics are socio-economic factors, public hardship, and implementation challenges. The output of the initial descriptive analysis of the survey data suggests that most survey respondents either 'strongly agree' or 'agree' with the nine measures perceived by the common man (general public) in Afghanistan (see figure 2, figure 3, figure 4, figure 5, figure 6, figure 7). According to (Bennett, 2003), demonetization was one of the most successful government decisions. The decision made monetary sustainability and economic recovery to the country; the practical monetary policy to limit new inflation is based on demonetization's remarkable value chain dynamics. Demonetization eliminates the various regional currencies circulation in the country. The better aligning global value chains with Afghanistan's international trade dynamics partners and regional neighbor countries, especially India and Pakistan. However, in Afghanistan, value chain dynamics have not helped the common man or small scale industries; it allows only riches and super-rich segments. Still, the common man (general public), despite bearing the challenges at the time of demonetization, has good insight towards the implemented policy for their country's better future. Therefore, we conclude that the improvisation of the value chain is because of demonetization in Afghanistan.

\section{LIMITATION OF THE STUDY}

The scope of this research study is on the common man (general public) in Afghanistan. The respondents are consist of daily wage workers, agriculturalists, shopkeepers, small business holders, and people from unorganized sectors, in general, the people who do not have a stable income. Hence the result might not directly indicate to the other segments of the general public. The sample for this research study is mainly composed of young generations above 25 years of age from Kabul and Parwan provinces who witnessed the demonetization policy implemented by the Government of Afghanistan in 2002. Hence, this study may not be directly applicable to those from other areas far from access to the banks. Therefore to simplify the result, further researches are encouraged in other sample frames, such as other provinces of Afghanistan and people from the organized sector class in a different context. 


\section{ACKNOWLEDGMENTS}

We want to thank Mr. Wahidullah Qahiry (operation officer in NHLP/MAIL/World Bank), Afghanistan, for the outstanding assistance of paving the way for the researcher to share the questionnaires among the agriculturalists in the different districts of Kabul and Parwan provinces of Afghanistan.

\section{REFERENCES}

Beg, S., \& Joshi, N. (2017). Public Perception of the Impact of Demonetization in India: An Empirical Study. Journal of Commerce \& Trade, 12(2). https://doi.org/10.26703/JCT.v12i2-11

Bennett, A. (2003). Islamic State of Afghanistan: Rebuilding a Macroeconomic Framework for Reconstruction and Growth. International Monetary Fund.

Briceno, A. J. H., \& de Hurtado, S. Z. (2019). India-Venezuela: Analysis of Demonetization Measures. International Journal of Advances in Management and Economics, 8(2), 11. Retrieved from https://www.researchgate.net/publication/332233986.

Cattell, R. B. (1966). The Screen Test For The Number Of Factors. Multivariate Behavioral Research, 1(2), 245-276. https://doi.org/10.1207/s15327906mbr0102_10

Chandrasekhar, C. P., \& Ghosh, J. (2018). The Financialization of Finance? Demonetization and the Dubious Push to Cashlessness in India: Debate: The Financialization of Finance in India. Development and Change, 49(2), 420-436. https://doi.org/10.1111/dech.12369

Chodorow-Reich, G., Gopinath, G., Mishra, P., \& Narayanan, A. (2020). Cash and the Economy: Evidence from India's Demonetization*. The Quarterly Journal of Economics, 135(1), 57-103. https://doi.org/10.1093/qje/qjz027

Chawla, D., \& Sondhi, N. (2016). Research Methodology Concept and Cases (Second Edition). Vikas Publishing House PVT LTD.

DAB. (2006). Quarterly Economic and Statistical Bulletin Combined Quarterly Issue (200506). Monetary Policy Department of Da Afghanistan Bank. Retrieved from https://dab.gov.af/sites/default/files/2019-01/DABQuarterlyBulletinCombinedIssue1384\%282005-2006\%29.pdf

Dash, A. (2017). A Study on Socio-Economic Effect of Demonetization in India. International Journal of Management and Applied Science,3(3), 4. Retrieved from http://iraj.in/journal/journal_file/journal_pdf/14-349-149485006913-15.pdf.

DeVellis, R. F. (2016). Scale Development: Theory and Applications11 (Fourth Edition). SAGE Publications.

Focus on the introduction of a new currency. (2002, September 5). The New Humanitarian. Retrieved from https://www.thenewhumanitarian.org/feature/2002/09/05/focusintroduction-new-currency 
Ghani, A., \& Lockhart, C. (2008). Fixing failed states: A framework for rebuilding a fractured world. Oxford University Press.

Ghosh, J., Chandrasekhar, C. P., \& Patnaik, P. (2017). Demonetisation decoded: A critique of India's currency experiment. Routledge.

Ghosh, S. (2016). Productivity, ownership, and firm growth: Evidence from Indian banks. International Journal of Emerging Markets, 11(4), 607-631. https://doi.org/10.1108/IJoEM-05-2015-0096

Hair, J. F., Black, W. C., Babin, B. J., Anderson, R. E., \& Tatham, R. L. (1998). Multivariate data analysis (Vol. 5, No. 3, pp. 207-219). Upper Saddle River, NJ: Prentice hall.

Kaiser, H. F. (1960). The application of electronic computers to factor analysis. Educational and Psychological Measurement, 20(1), 141151.https://doi.org/10.1177/001316446002000116

Kaiser, H. F. (1974). An index of factorial simplicity. Psychometrika, 39(1), 31-36. https://doi.org/10.1007/BF02291575

Knaap, P.V.D., Vries, T. D., \& Boesenach, E. (2018). World Cash report (p. 196). Retrieved from https://cashessentials.org/app/uploads/2018/07/2018-world-cash-report.pdf

Kumar, P. (2017). Demonetization and its Impact on Adoption of Digital Payments: Opportunities, Issues, and Challenges. Abhinav National Monthly Refereed Journal of Research in Commerce \& Management. 6(6), 15. Retrieved from https://www.researchgate.net/publication/317283897

Mahajan, P., \& Singla, A. (2017). Effect of Demonetization on Financial Inclusion in India. International Journal of Science Technology and Management (IJSTM).Vol. No.6,(Issue No.01), $6 . \quad$ Retrieved from https://www.ijstm.com/images/short_pdf/1484056964_N360_IJSTM.pdf.

Mukherjee, R. (2019). Jio sparks Disruption 2.0: Infrastructural imaginaries and platform ecosystems in 'Digital India.' Media, Culture \& Society, SAGE Publication, 41(2), 175195. https://doi.org/10.1177/0163443718818383

Nair, A. K. S., \& Bhattacharyya, S. S. (2019). Is sustainability a motive to buy? An exploratory study in the context of mobile applications channel among young Indian consumers. Emerald Insight Foresight, 21(2), 177-199. https://doi.org/10.1108/FS-05-2018-0048

Netemeyer, R. G., Bearden, W. O., \& Sharma, S. (2003). Scaling Procedures: Issues and Applications. SAGE Publications.

Panah, A. M., \& Muniraju, Y. (2019). Demonetization, economic restructuring, and monetary sustainability in war-prone Afghanistan. Asian Journal of Multidimensional Research (AJMR), 8(3), 509. https://doi.org/10.5958/2278-4853.2019.00127.7 
Prasad, S. R. (2019). Measuring the efficiency of indian real estate firms during the pre-and post-demonetization period by adopting data envelopment analysis. Baltic Journal of Real Estate Economics and Construction Management, 7(1), 98-109.

Ramchandra Gowda, M., Aswatha Narayana, T., Ravi, M. V., \& Srinivas, K. T. (2014). Monetary System (Second Revised Edition). Himalaya Publishing House Pvt Ltd. Retrieved from www.himpub.com

Sharma, C. (2019). Estimating the size of the black economy: New evidence from India. International Journal of Emerging Markets, 14(2), 300-321. https://doi.org/10.1108/IJoEM-01-2018-0034

Singh, P., Sawhney, R. S., \& Kahlon, K. S. (2018). Sentiment analysis of demonetization of 500 \& 1000 rupee banknotes by the Indian government. ICT Express, 4(3), 124-129. https://doi.org/10.1016/j.icte.2017.03.001

Sivathanu, B. (2019). Adoption of digital payment systems in the era of demonetization in India: An empirical study. Journal of Science and Technology Policy Management, 10(1), 143-171. https://doi.org/10.1108/JSTPM-07-2017-0033

Swain, D. R. K., \& Das, C. P. (2018). Economic Consequences of Demonetization: A Comparative Analysis. Orissa Journal of Commerce, Vol.III, pp 1-7, 103. Retrieved from https://ojcoca.org/jan18.pdf.

Singh, K. Y. (2006). Fundamental of Research Methodology and Statistics. New Age International (P) Limited, Publishers. Retrieved from www.newagepublishers.com.

Thakur, R., \& Srivastava, M. (2013). Customer usage intention of mobile commerce in India: An empirical study. Journal of Indian Business Research, 5(1), 52-72. https://doi.org/10.1108/17554191311303385

Vij, D. D. (2018). Demonetization: Effects on the Indian Economy. International Research Journal of Business and Management-IRJBM, Volume No-XI(Issue - 1), 11. Retrieved from http://irjbm.org/irjbm2013/Jan18/Abstract15.pdf.

\section{Copyrights}

Copyright for this article is retained by the author(s), with first publication rights granted to the journal. This is an open-access article distributed under the terms and conditions of the Creative Commons Attribution license (http://creativecommons.org/licenses/by/4.0/) 